\title{
Effect of Biogenic Silica Nanoparticles on Blast and Brown Spot Diseases of Rice and Yield Component \\ Gabr, W. E. ${ }^{\text {; }}$ A. A. Hassan ${ }^{1}$; I. M. Hashem ${ }^{2}$ and Zeinab A. Kalboush ${ }^{1}$ \\ ${ }^{1}$ Rice Pathol. Dept., Plant Pathol. Res. Inst., Agric. Res. Center, Egypt. \\ ${ }^{2}$ Rice Dept., field crops Res. Inst., Agric. Res. Center, Egypt. \\ Corresponding author: E-mail, zeinab.rrtc@yahoo.com
}

\section{ABSTRACT}

Rice is considered as one of the most important food crops in the world. Rice plants infected by several plant pathogens. In Egypt, however important diseases of rice namely blast and brown spot are major limitation on rice production and becoming more sever on rice grown in silicon depleted soil. Disease that occurs to plant may reduce the ability of the plant to survive and in more severe cases could eventually lead to plant death. Two field experiments were carried out to study the effect of different sources of biogenic silica nanoparticles on blast, brown spot diseases and yield component in rice at Rice Research and Training Center Experimental Farm, Sakha, Kafr El-Sheikh, Egypt. The effect of different sources of silica on the behavior and infection by rice blast on Sakha 101 rice variety had been studied in the first experiment. While the second experiment included the behavior and infection by brown spot of Egyptian Hybrid Rice One under silica nanoparticles biogenic treatments. The silica treatments were white rice husk, rice husk nanoparticles, white rice straw, rice straw nanoparticles, $\mathrm{Mg}_{2} \mathrm{O}_{8} \mathrm{Si}_{3}$, and $\mathrm{K}_{2} \mathrm{SiO}_{2}$. Chemical fungicides (Beam and Del-Cup) and tap water were used as control. Different biogenic and chemical silica led to decreasing blast disease infection in Sakha 101 compared with control (tap water). Most of the agronomic characters of Sakha 101 were affected significantly by different treatments. All treatment of different biogenic and chemical silica sources decreased the leaf infection percent and severity for brown spot disease on Egyptian Hybrid Rice One. Different treatments significantly affected panicle length, number of filled grains per panicle, number of unfilled spikelets per panicle, 1000-grain weight, and grain yield and harvest index of Egyptian Hybrid Rice One. The result of this study suggests that silica caused decrease the intensity of blast and brown spot diseases.

Keywords: white rice husk, rice husk nanoparticles, white rice straw, rice straw nanoparticles, Magnaporthe oryzae, Bipolaris oryzae

\section{INTRODUCTION}

Rice is one of the most important food security crops and as a result of population increase; the demand for rice has increased year after year. Rice production has to be increased to cover the rice needs all over the world.

The most important diseases on rice in Egypt are rice blast (Magnaporthe oryzae), brown spot (Cochliobolus miyabeanus), bakanae rice disease (Fusarium moniliforme), and sheath blight (Rhizoctonia solani). This study focused on rice blast and brown spot. Rice blast is one of the most important diseases on rice. It is caused by the hemi-biotrophic fungus $M$. oryzae and can infect all aerial parts of rice, leading to neck and panicle rot, collar rot, leaf blast and node blast. Annual losses caused by rice blast can vary between $10 \%$ and $30 \%$ of the harvest. Brown spot is caused by the necrotrophic fungus $C$. miyabeanus (teleomorph) or Bipolaris oryzae (anamorph). It is one of the most divesting and prevalent disease of rice (Ou 1985). C. miyabeanus can also cause blight on small rice seedlings (Webster and Gunnell 1992). In plants broad spectrum resistance is a rare phenomenon. Often when a plant is tolerant towards one type of stress, trade-offs occur making the same plant more susceptible towards another type of stress. The only exception is $\mathrm{Si}$, which is well known to protect plants against different pathogens: M. oryzae, Xanthomonas oryzae pv. oryzae, $C$ miyabeanus and $R$ solani (Van Bockhaven et al., 2012).

Silicon is an important and necessary element for rice growth, which has useful effects on rice growth. In shortage of $\mathrm{Si}$, the plant goes to nutritional tribulation. Therefore, $\mathrm{Si}$ causes plant resist against pests and illnesses, so it is recommended that in mineral nutrition argument of rice silicate fertilizer should be used. Moghadam and Heidarzadeh 2014 surveyed pure silicate fertilizer, rice husk and rice husk ash at different levels on rice. They reported that by applying related treatments morphological specifications, plant height, number of tillers, leaf area, leaf stem and total dry weight and silicon density in leaf texture and stem and a progressive process which in tillering stage was significant $1 \%$ level. Also by applying treatments at different levels there was witness of increasing in grain yield that was significant at 5\% level.

Silicon application increases rice resistance to blast on both partially resistant and susceptible cultivars (Seebold et al., 2001). Rodrigues et al. (2004) discovered that infected leaves of Si- plants ( $\mathrm{Si}$ nonamended plants) displayed intense chlorosis compared with the leaves of $\mathrm{Si}+$ plants ( $\mathrm{Si}$ amended plants). It was described that Si merely acts as a physical barrier, due to the silica deposition in the leaves, which hampers fungal penetration into the epidermis. Later it became increasingly clear that this passive role of $\mathrm{Si}$ is not the only determinant for the Si-elicited stress protection (Jones and Handreck, 1967). Silicon-induced brown spot resistance is the result of a constriction of the fungal progression in the mesophyll. The role of ROS, accumulation of lignin and callose seem to be negligible factors in the resistance. Very few reports suggest that $\mathrm{Si}$ application might lead to a very timely and local boost in ROS production leading to resistance (Ghareeb et al., 2011; Sun et al. 2010; Shetty et al., 2012). More articles can be found on the ROS catching effect of Si during infection and abiotic stress (Liang et al. 2005; Nwugo and Huerta 2011; Van Bockhaven et al. 2012).

The purpose of this study is to use natural sources of silica to increase the resistance of rice plants to blast and brown spot as alternative methods of fungicide use and increase of quality and grain yield. 


\section{MATERIALS AND METHODS}

1: Silica sources $\{$ biogenic nanoparticles (Si NPs) and chemical Silica\}: The author in previous study (Kalboush, et al., 2017) had perpetrated and synthesized biogenic nanoparticles to obtain white rice straw (WRS), rice straw nanoparticles (RSNPs) with $\mathrm{SiO} 2$ content of $55.72 \%$, white rice husk (WRH) and rice husk nanoparticles (RHNPs) with $\mathrm{SiO} 2$ content of $76.3 \%$, from Kalboush, et al., 2017. The particles size for RSNPs and RHNPs were $73.6 \mathrm{~nm}$ and $133.7 \mathrm{~nm}$ with spherical shape. Size and morphology of Silica nanoparticles were confirmed by X-ray diffraction (XRD) and transmission electron microscopy (TEM). Concentrations of RSNPs and RHNPs sterile deionized water. All solutions were stored at $4^{\circ} \mathrm{C}$ until use. The chemical sources of silica were $\mathrm{Mg}_{2} \mathrm{O}_{8} \mathrm{Si}_{3}$ and $\mathrm{K}_{2} \mathrm{SiO}_{2}$ with $25 \%(\mathrm{w} / \mathrm{v})$ of $\mathrm{SiO}_{2}$ content.

2. Effect of different sources of silica on rice blast and brown spot diseases incidence: The present investigation was carried out at the Experimental Farm of Rice Research and Training Center (RRTC), Sakha, Kafr El-Sheikh, Egypt, during 2015 and 2016 seasons. The effect of sprayed with biogenic Si NPs chemical Silica on blast and brown spot diseases, and yield component on rice.

Two separated experiments were carried out; in the first experiment Sakha 101 as susceptible rice cultivar for rice blast disease was used while Egyptian hybrid 1 used for rice brown spot in the second experiment.

Different treatments of biogenic, chemical silica, fungicides with determined concentration plus control (water) were used in complete randomized block design in both experiments as indicated below:

\begin{tabular}{lc}
\hline Treatment & Concentration \\
\hline 1. White rice husk (WRH) & $0.45 \mathrm{~g} / 1$ \\
2. Rice husk nanoparticles (RHNPs) & $0.45 \mathrm{~g} / 1$ \\
3. White rice Straw (WRS) & $0.45 \mathrm{~g} / 1$ \\
4. Rice Straw nanoparticles (RSNPs) & $0.45 \mathrm{~g} / 1$ \\
5. Mg2O8 Si3 & $2 \mathrm{~g} / 1$ \\
6. Mg2O8 Si3 & $3 \mathrm{~g} / 1$ \\
7. K2SiO2 & $2 \mathrm{ml} / 1$ \\
8. K2 SiO2 & $3 \mathrm{ml} / 1$ \\
9. Beam (Tricyclazole) fungicide in & $0.5 \mathrm{~g} / 1$ \\
Exp.1 & $5 \mathrm{ml} / 1$ \\
OrDel Cup (Copper Sulfate Pentahydrate) & 0 \\
Exp.2 & \\
10. Control & \\
\hline
\end{tabular}

All treatment sprayed at 30 days after transplanting and booting stages. Nitrogen fertilizer supplied in the form of urea $(46.5 \% \mathrm{~N})$ in two equal splits, i.e., half as basal incorporated into the dry soil immediately before flooding, followed by the second dose 30 days after transplanting. Pre-germinated seeds were uniformly broadcasted in the nursery on 6th and 9th May of the two seasons, respectively. Twenty-five day old seedlings of each genotype were transplanted at 20 X $20 \mathrm{~cm}$ spacing with two seedlings per hill. Plot size was $12 \mathrm{~m}^{2}$. All other agronomic practices were followed as recommended during the growing seasons.

\section{Disease assessment:}

One hundred leaves were randomly collected from each plot to determine leaf blast and brown spot infection at intervals of 15 days started from the appearance of primary infection. Percentage of the infected leaves was calculated, while severity of infection was estimated by counting the total number of infection (type 4 lesion type or more) blast lesions/100 leaves. Neck rot infection was estimated by collecting one hundred panicles from each plot one week before harvesting. The severity of neck rot infection was calculated using the formula adopted by Townsend \& Huberger (1943) as follows:

$$
S=\frac{\operatorname{sum}(n \times v)}{10 N} \times 100
$$

Where:

$\mathrm{S}=$ severity of panicle blast infection,

$\mathrm{n}=$ number of panicles within infection category

(from one with one infected primary branch of

the panicle to 10 for the complete infection in

the uppermost internode of the panicle as neck

infection);

$\mathrm{V}=\quad$ numerical values of infection categories,

$\mathrm{N}=\quad$ Total number of panicles, and

$10=$ constant, highest numerical value

4-Agronomic characters: The studied characters include plant height $\mathrm{cm}$, number of tillers per hill, panicle length $(\mathrm{cm})$, number of filled grains per panicle, number of unfilled spikelets per panicle, 1000 -grain weight $(\mathrm{g})$, grain yield $\left(\mathrm{t} \mathrm{ha}^{-1}\right)$, straw yield $\left(\mathrm{t} \mathrm{ha}{ }^{-1}\right)$, and harvest index.

5-Data Analysis: Data were statistically analyzed using analysis of variance (ANOVA) of the complete block design was applied in field experiments. The complete block design was adopted according to Gomez and Gomez (1984). The treatment means were compared using the least significant difference (LSD) at $5 \%$.

\section{RESULTS AND DISCUSSION}

Characterization of Silica NPs:

Characterization by X-ray diffraction (XRD): The Xray diffraction of RSNPs showed a broad between $27^{\circ}$ and $32^{\circ}$, centered at $23^{\circ}$, typical for amorphous silica (Fig. 1A). On the other hand, X-ray diffraction of RHNPs showed a broad between $20^{\circ}$ and $30^{\circ}$, centered at $30^{\circ}$, typical for amorphous silica (Fig. 1B). XRD pattern of RHNS shows a broad peak at $2 \Theta=220$ which confirms the amorphous nature of RHNS (Dominic et al., 2013). 

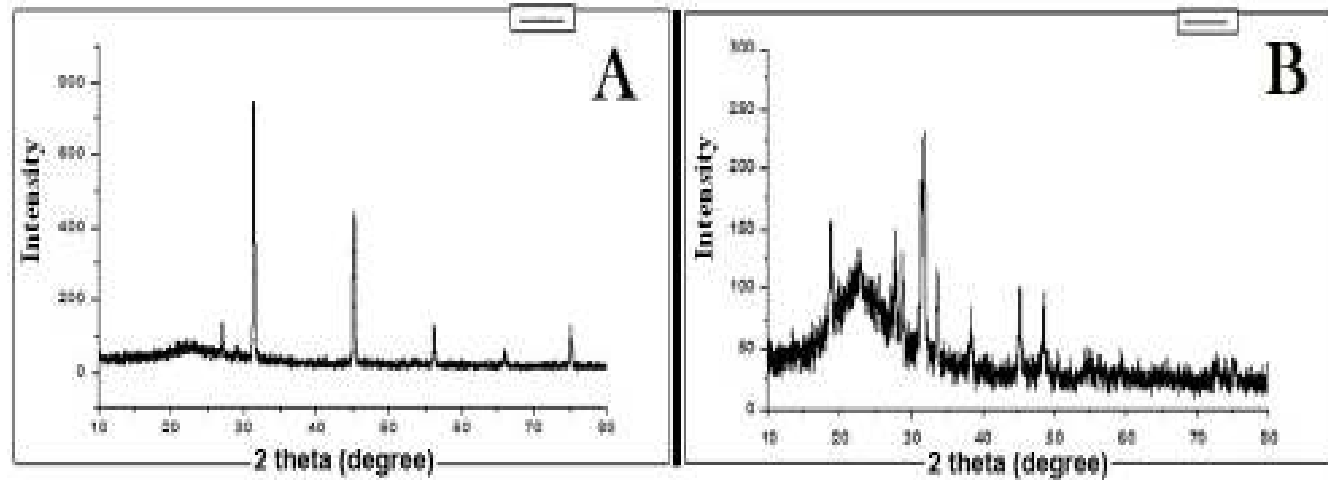

Fig 1: X-ray diffraction of synthesized rice straw nanoparticles (A) and rice husk nanoparticles (B). TEM images of samples dried from highly diluted RHNPs and RSNPs suspension on carbon grid surface showed the dispersed silica to be of spherical shape and size particle $73.6 \mathrm{~nm}$ and $133.7 \mathrm{~nm}$, respectively shown in fig. (2).

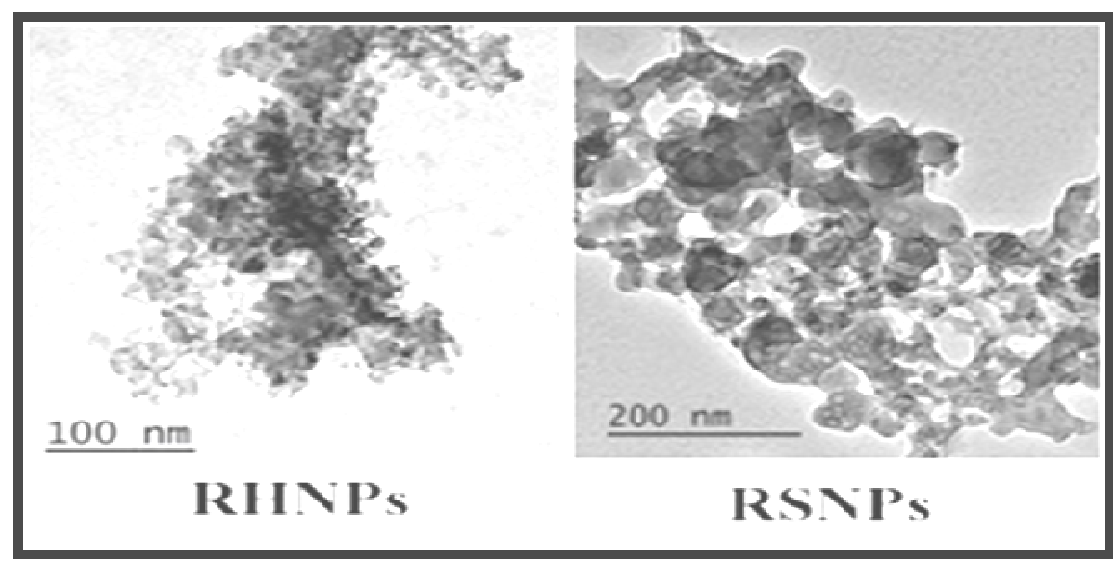

Fig.2: TEM images of RHNPs and RSNPs.

Effect of biogenic and chemical silica on rice blast disease incidence.

Different biogenic and chemical silica led to reduction in blast disease infection in the treated rice leaves of Sakha $101 \mathrm{cv}$ compared with untreated control (tap water). The best treatments were observed in treatments of beam, $\mathrm{K}_{2} \mathrm{SiO}_{2} 3 \mathrm{ml} / 1, \mathrm{~K}_{2} \mathrm{SiO}_{2} 2 \mathrm{ml} / 1$ that produced 4.00, 14.0 and 16.0 spot/ 100 leaves respectively for flag leaf infection (Table 1). RHNPs and RSNPs showed promising results compared with control in reduction of rice blast disease and produced 13.0 and $22.0 \mathrm{spot} / 100$ leaves, respectively for flag leaf infection (Table 1).

Data presented in Table (2) of panicle blast infection in experiment 2 showed that Beam and $\mathrm{K}_{2} \mathrm{SiO}_{2}$ treatments gave the best result followed by RHNPs and RSNPs which gave the promising results compared with control with high infection of panicle and lowest grain yield. The application of Si to rice plants to control rice blast is an alternative approach that is gaining increased interest (Park et al. 2006; Rodrigues et al. 2003). Normally blast can be controlled through chemical fungicides, this will lead to the establishment of races of the pathogen resistant to these chemicals and the pesticides have a negative effect to the environment (Gao et al. 2011). Using Si for disease control is both economically viable and environmentally friendly (Abed-Ashtiani et al. 2012; Sun et al. 2010). However, given its universal nature, the beneficial effect of $\mathrm{Si}$ is only noticeable in soils that are Si deficient, like most rice fields (Foy, 1992)

Silicon application increases rice resistance to blast on both partially resistant and susceptible cultivars (Seebold et al. 2001). Rodrigues et al. (2004) discovered that infected leaves of Si- plants ( $\mathrm{Si}$ non-amended plants) displayed intense chlorosis compared with the leaves of $\mathrm{Si}+$ plants ( $\mathrm{Si}$ amended plants). It was described that Si merely acts as a physical barrier, due to the silica deposition occurred in both adaxial and abaxical leaf blades of rice plant that received $\mathrm{Si}$, which hampers fungal penetration into the epidermis. In the leaf blades of rice $\mathrm{Si}$ is deposited on a $2.5 \mu \mathrm{m}$ layer right beneath the $0.1 \mu \mathrm{m}$ cuticle layer thus forming affine cuticle -Si double layer (Ma and Takahashi, 2002). This double cuticle layer protects plant from multiple biotic and abiotic stresses. Later it became increasingly clear that this passive role of $\mathrm{Si}$ is not the only determinant for the Si-elicited stress protection (Jones and Handreck 1967).

In addition, application of $\mathrm{Si}$ contributes to hypersensitive cell death (Rodrigues et al. 2005) and increases the epidermal cell wall thickness of rice leaves (Kim et al. 2002). Silicon also affects the response of rice to rice blast at a transcriptional level (Brunings et al., 2009). 
Gabr, W. E. et al.

Table 1. Effect of silica sources on leaf percent and severity infection of rice blast disease on Sakha 101 rice cultivar under field conditions in 2015 and 2016 seasons.

\begin{tabular}{|c|c|c|c|c|c|c|c|c|c|}
\hline \multirow[t]{2}{*}{ Treatment } & \multirow[t]{2}{*}{ Conc. } & \multicolumn{2}{|c|}{ Leaf infection \% } & \multicolumn{2}{|c|}{$\begin{array}{c}\text { Severity (Spot } \\
100 \text { leaves) }\end{array}$} & \multicolumn{2}{|c|}{ Flag Leaf \% } & \multicolumn{2}{|c|}{ Severity flag } \\
\hline & & 2015 & 2016 & 2015 & 2016 & 2015 & 2016 & 2015 & 2016 \\
\hline White rice husk & $0.45 \mathrm{~g} / 1$ & 29.33 & 28.00 & 52.0 & 36.00 & 18.67 & 18.67 & 46.67 & 28.00 \\
\hline Rice husk nanoparticles & $0.45 \mathrm{~g} / 1$ & 20.00 & 22.67 & 37.3 & 29.33 & 10.67 & 10.67 & 26.67 & 13.33 \\
\hline White rice Straw & $0.45 \mathrm{~g} / 1$ & 34.67 & 32.00 & 60.0 & 44.00 & 21.33 & 21.33 & 54.67 & 22.67 \\
\hline Rice Straw nanoparticles & $0.45 \mathrm{~g} / 1$ & 24.00 & 25.33 & 44.0 & 32.00 & 18.67 & 18.67 & 41.33 & 22.67 \\
\hline $\mathrm{Mg}_{2} \mathrm{O}_{8} \mathrm{Si}_{3}$ & $2 \mathrm{~g} / 1$ & 22.67 & 22.67 & 41.3 & 32.00 & 17.33 & 17.33 & 37.33 & 20.00 \\
\hline $\mathrm{Mg}_{2} \mathrm{O}_{8} \mathrm{Si}_{3}$ & $3 \mathrm{~g} / 1$ & 20.00 & 18.67 & 38.7 & 25.33 & 13.33 & 13.33 & 36.00 & 17.33 \\
\hline $\mathrm{K}_{2} \mathrm{SiO}_{2}$ & $2 \mathrm{ml} / 1$ & 21.33 & 21.33 & 36.0 & 26.67 & 14.67 & 14.67 & 33.33 & 16.00 \\
\hline $\mathrm{K}_{2} \mathrm{SiO}_{2}$ & $3 \mathrm{ml} / 1$ & 20.00 & 14.67 & 36.0 & 18.67 & 12.00 & 12.00 & 32.00 & 14.67 \\
\hline Beam & $0.5 \mathrm{~g} / 1$ & 9.33 & 5.33 & 21.3 & 8.00 & 2.67 & 2.67 & 17.33 & 4.00 \\
\hline Control & - & 57.33 & 44.00 & 241.3 & 160.00 & 36.00 & 36.00 & 197.33 & 106.67 \\
\hline L.S.D. 0.05 & & 5.537 & 5.087 & 26.69 & 7.876 & 4.719 & 4.719 & 9.368 & 7.626 \\
\hline
\end{tabular}

Table 2. Effect of silica sources on panicle percent and severity infection of rice blast disease on Sakha 101 rice cultivar under field conditions in 2015 and 2016 seasons.

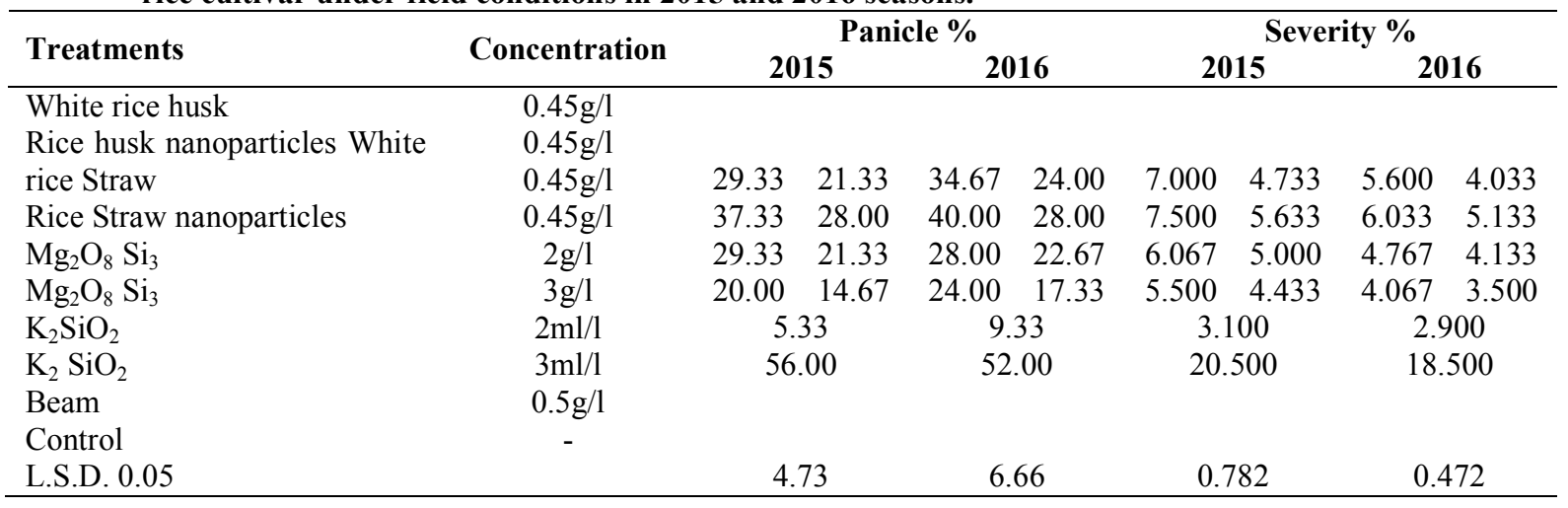

Agronomic and yield studied characters are affected significantly by different treatments on Sakha 101 rice cultivar.

Panicle length, number of filled grains per panicle, number of unfilled spikelets per panicle, 1000grain weight, grain yield, straw yield and harvest index were affected significantly by different treatments (Tables 3, 4 and 5). On the other hand, plant height and number of tillers per hill were not affected. Application of beam recorded the highest values of panicle length, number of filled grains per panicle, 1000-grain weight, grain yield, straw yield and harvest index. The lowest number of unfilled spikelets per panicle was recorded when beam was applied without any significant difference with RHNPS. Control treatment (tap water spray) recorded the lowest values of panicle length, number of filled grains per panicle, 1000-grain weight, grain yield, straw yield and harvest index. Ahmed et al. 2013 reported that plant height, number of tillers per plant, number of productive tillers, abortive kernal, while straw yield, branches per panicle, spike per panicle, 1000 grain weight, paddy yield, grain starch were performed better where silica was applied to rice plants. Gholami and Falah, 2013 found that siliceous fertilizers significantly increased stems and leaves silicon concentration, tiller number, leaves dry weight, 1000-grain weight and yield. These results are in agreement with those reported by Moghadam and Heidarzadeh, 2014.

Table 3. Effect of silica sources on plant height, no. of tillers and panicle length on Sakha 101 rice cultivar under field conditions in 2015 and 2016 seasons.

\begin{tabular}{|c|c|c|c|c|c|c|c|}
\hline \multirow{2}{*}{ Treatments } & \multirow{2}{*}{ Conc. } & \multicolumn{2}{|c|}{ Plant height cm } & \multicolumn{2}{|c|}{ No. of tillers hill-1 } & \multicolumn{2}{|c|}{ Panicle length $\mathrm{cm}$} \\
\hline & & 2015 & 2016 & 2015 & 2016 & 2015 & 2016 \\
\hline White rice husk & $0.45 \mathrm{~g} / 1$ & 90.07 & 91.23 & 23.63 & 25.33 & 24.13 & 24.13 \\
\hline Rice husk nanoparticles White & $0.45 \mathrm{~g} / 1$ & 89.67 & 90.07 & 24.00 & 25.33 & 25.40 & 25.07 \\
\hline rice Straw & $0.45 \mathrm{~g} / 1$ & 89.33 & 91.30 & 23.63 & 24.60 & 24.07 & 23.94 \\
\hline Rice Straw nanoparticles & $0.45 \mathrm{~g} / 1$ & 90.00 & 90.20 & 23.43 & 25.33 & 25.10 & 24.80 \\
\hline $\mathrm{Mg}_{2} \mathrm{O}_{8} \mathrm{Si}_{3}$ & $2 \mathrm{~g} / 1$ & 88.70 & 90.63 & 24.33 & 25.00 & 25.37 & 25.13 \\
\hline $\mathrm{Mg}_{2} \mathrm{O}_{8} \mathrm{Si}_{3}$ & $3 g / 1$ & 89.33 & 91.13 & 24.67 & 25.00 & 25.43 & 25.07 \\
\hline $\mathrm{K}_{2} \mathrm{SiO}_{2}$ & $2 \mathrm{ml} / 1$ & 89.33 & 90.47 & 25.00 & 24.67 & 25.27 & 25.17 \\
\hline $\mathrm{K}_{2} \mathrm{SiO}_{2}$ & $3 \mathrm{ml} / 1$ & 88.67 & 90.47 & 25.00 & 25.00 & 25.43 & 25.20 \\
\hline Beam & $0.5 \mathrm{~g} / 1$ & 87.67 & 90.77 & 25.67 & 25.33 & 26.60 & 26.81 \\
\hline Control & - & 87.67 & 90.80 & 23.67 & 24.00 & 23.20 & 22.87 \\
\hline L.S.D. 0.05 & & NS & NS & NS & NS & 0.52 & 0.68 \\
\hline
\end{tabular}


Table 4. Effect of silica sources on no. of filled grain, no. of unfilled spikelets and 1000-grain weight on Sakha 101 rice cultivar under field conditions in 2015 and 2016 seasons.

\begin{tabular}{|c|c|c|c|c|c|c|c|}
\hline \multirow[t]{2}{*}{ Treatments } & \multirow[t]{2}{*}{ Conc. } & \multicolumn{2}{|c|}{$\begin{array}{l}\text { No. of filled grain } \\
\text { panicle }^{-1}\end{array}$} & \multicolumn{2}{|c|}{$\begin{array}{c}\text { No. of unfilled } \\
\text { spikelets panicle }{ }^{-1}\end{array}$} & \multicolumn{2}{|c|}{ 1000-grain weight } \\
\hline & & 2015 & 2016 & 2015 & 2016 & 2015 & 2016 \\
\hline White rice husk & $0.45 \mathrm{~g} / 1$ & 84.63 & 85.70 & 7.93 & 7.07 & 27.47 & 27.00 \\
\hline Rice husk nanoparticles White & $0.45 \mathrm{~g} / 1$ & 91.20 & 91.20 & 4.97 & 5.30 & 28.17 & 28.10 \\
\hline rice Straw & $0.45 \mathrm{~g} / 1$ & 85.07 & 87.03 & 7.80 & 8.80 & 27.17 & 27.90 \\
\hline Rice Straw nanoparticles & $0.45 \mathrm{~g} / 1$ & 90.17 & 92.80 & 9.83 & 7.22 & 27.90 & 28.13 \\
\hline $\mathrm{Mg}_{2} \mathrm{O}_{8} \mathrm{Si}_{3}$ & $2 \mathrm{~g} / 1$ & 91.47 & 91.97 & 8.53 & 8.03 & 27.93 & 28.07 \\
\hline $\mathrm{Mg}_{2} \mathrm{O}_{8} \mathrm{Si}_{3}$ & $3 g / 1$ & 92.50 & 92.27 & 7.50 & 7.73 & 28.17 & 28.23 \\
\hline $\mathrm{K}_{2} \mathrm{SiO}_{2}$ & $2 \mathrm{ml} / 1$ & 91.30 & 90.97 & 6.70 & 9.03 & 28.27 & 28.29 \\
\hline $\mathrm{K}_{2} \mathrm{SiO}_{2}$ & $3 \mathrm{ml} / 1$ & 94.93 & 93.40 & 7.77 & 7.50 & 28.60 & 28.77 \\
\hline Beam & $0.5 \mathrm{~g} / 1$ & 95.47 & 94.93 & 4.53 & 5.08 & 28.83 & 28.93 \\
\hline Control & - & 80.37 & 81.60 & 19.63 & 15.40 & 26.53 & 25.87 \\
\hline L.S.D. 0.05 & & 1.99 & 2.09 & 1.99 & 2.48 & 0.49 & 0.63 \\
\hline
\end{tabular}

Table 5. Effect of silica sources on grain yield, straw yield and harvest index on Sakha 101 rice cultivar under field conditions in 2015 and 2016 seasons.

\begin{tabular}{lccccccc}
\hline \multirow{2}{*}{ Treatments } & \multirow{2}{*}{ Concentration } & \multicolumn{2}{c}{ Grain yield t ha } & \multicolumn{2}{c}{ Straw yield t ha $^{-1}$} & \multicolumn{2}{c}{ Harvest index } \\
& & $\mathbf{2 0 1 5}$ & $\mathbf{2 0 1 6}$ & $\mathbf{2 0 1 5}$ & $\mathbf{2 0 1 6}$ & $\mathbf{2 0 1 5}$ & $\mathbf{2 0 1 6}$ \\
\hline White rice husk & $0.45 \mathrm{~g} / 1$ & 9.55 & 9.89 & 13.31 & 14.03 & 0.418 & 0.413 \\
Rice husk nanoparticles & $0.45 \mathrm{~g} / 1$ & 10.93 & 11.10 & 14.33 & 14.89 & 0.433 & 0.427 \\
White rice Straw & $0.45 \mathrm{~g} / 1$ & 10.44 & 10.72 & 13.91 & 14.22 & 0.429 & 0.430 \\
Rice Straw nanoparticles & $0.45 \mathrm{~g} / 1$ & 10.49 & 10.82 & 13.66 & 13.99 & 0.434 & 0.436 \\
$\mathrm{Mg}_{2} \mathrm{O}_{8} \mathrm{Si}_{3}$ & $2 \mathrm{~g} / 1$ & 10.62 & 10.98 & 14.08 & 14.15 & 0.430 & 0.437 \\
$\mathrm{Mg}_{2} \mathrm{O}_{8} \mathrm{Si}_{3}$ & $3 \mathrm{~g} / 1$ & 10.91 & 11.09 & 14.12 & 14.38 & 0.436 & 0.435 \\
$\mathrm{~K}_{2} \mathrm{SiO}_{2}$ & $2 \mathrm{ml} / 1$ & 10.94 & 10.94 & 14.08 & 14.24 & 0.437 & 0.434 \\
$\mathrm{~K}_{2} \mathrm{SiO}_{2}$ & $3 \mathrm{ml} / 1$ & 11.02 & 11.27 & 14.68 & 14.87 & 0.429 & 0.431 \\
$\mathrm{Beam}$ & $0.5 \mathrm{~g} / 1$ & 11.57 & 11.72 & 14.79 & 15.02 & 0.439 & 0.438 \\
Control & - & 8.10 & 8.08 & 12.22 & 12.82 & 0.399 & 0.387 \\
L.S.D. 0.05 & & 0.24 & 0.17 & 0.96 & 0.53 & 0.018 & 0.011 \\
\hline
\end{tabular}

Effect of biogenic and chemical silica on rice brown spot disease incidence.

Results indicated that all treatment of different biogenic and chemical silica sources decreased the leaf infection percent and severity for brown spot disease. The highest treatment was obtained from RHNPs, RSNPs, $\mathrm{K}_{2} \mathrm{SiO}_{2}$ and $\mathrm{Mg}_{2} \mathrm{O}_{8} \mathrm{Si} 3$ in tables (6 and 7).

The application of $\mathrm{Si}$ leads to a reduction in brown spot disease severity that ranges between 40 and 70\%. Ghareeb et al. 2011; Sun et al. 2010; Shetty et al. 2012 reported that The efficacy of Si treatment depends on the scoring method, used cultivar, growing conditions, but $\mathrm{Si}$ always induces a significant reduction in disease severity. However, $\mathrm{Si}$ only gives a full range of protection when it is applied continuously and the active effect of Si-application caused by silicic acid in the plant cells is dominant over the passive effect of the silica deposition in the leaves in conferring Si-induced brown spot resistance. Silicon-induced brown spot resistance is the result of a constriction of the fungal progression in the mesophyll. Silica application to resulted in more pronounced cell silicate in leaves and papilla's who more extracted and larger. Silicon layers were formed in the epidermal cell walls of rice and increasing $\mathrm{Si}$ treatment increase the thickness of the layer resulting in improving levels of resistance to brown spot (Ning et al., 2014). The role of ROS, accumulation of lignin and callose seem to be negligible factors in the resistance. Very few reports suggest that Si application might lead to a very timely and local boost in ROS production leading to resistance. More articles can be found on the ROS catching effect of $\mathrm{Si}$ during infection and abiotic stress (Liang et al. 2005; Nwugo and Huerta 2011; Van Bockhaven et al. 2012). With the application of $\mathrm{Si}$, rice plants seem to have more phenolic compounds. These compounds have antimicrobial activity and their polymerization and cross-linking leads to the accumulation of lignin and cell wall fortification, which hamper pathogens at the site of infection (Rodrigues et al. 2005). C. miyabeanus can produce toxins that down regulate the PAL pathway and accumulation of phenolic compounds leading to susceptibility (Vidhyasekaran et al. 1992). However, the phenolic compounds probably have a fungi toxic effect on C. miyabeanus, resulting in hampered mesophyllic growth inside rice leaves. Silicon-induced resistance to diseases is linked to an accumulation of phenolic compounds. Many authors link this to the deposition of silica at the site of infection (Zeyen et al. 1993). 
Gabr, W. E. et al.

Table 6. Effect of silica sources on leaf percent and severity infection of rice brown spot disease on Egyptian hybrid rice one cultivar under field conditions in 2015 and 2016 seasons.

\begin{tabular}{|c|c|c|c|c|c|c|c|c|c|}
\hline \multirow[t]{2}{*}{ Treatment } & \multirow[t]{2}{*}{ Concentration } & \multicolumn{2}{|c|}{$\begin{array}{c}\text { Leaf infection } \\
\%\end{array}$} & \multicolumn{2}{|c|}{$\begin{array}{c}\text { Severity (Spot } \\
100 \text { leaves) }\end{array}$} & \multicolumn{2}{|c|}{ Flag Leaf \% } & \multicolumn{2}{|c|}{ Severity flag } \\
\hline & & 2015 & 2016 & 2015 & 2016 & 2015 & 2016 & 2015 & 2016 \\
\hline White rice husk & $0.45 \mathrm{~g} / 1$ & 20.00 & 28.00 & 92.00 & 92.00 & 16.00 & 18.67 & 52.00 & 29.33 \\
\hline Rice husk nanoparticles & $0.45 \mathrm{~g} / 1$ & 12.00 & 40.00 & 57.33 & 54.67 & 10.67 & 9.33 & 49.33 & 22.67 \\
\hline White rice Straw & $0.45 \mathrm{~g} / 1$ & 36.00 & 29.33 & 112.00 & 112.00 & 25.33 & 25.33 & 88.67 & 49.33 \\
\hline Rice Straw nanoparticles & $0.45 \mathrm{~g} / 1$ & 28.00 & 22.67 & 100.00 & 84.00 & 21.33 & 21.33 & 76.00 & 32.00 \\
\hline $\mathrm{Mg}_{2} \mathrm{O}_{8} \mathrm{Si}_{3}$ & $2 \mathrm{~g} / 1$ & 20.00 & 17.33 & 61.33 & 64.00 & 16.00 & 16.00 & 52.00 & 34.67 \\
\hline $\mathrm{Mg}_{2} \mathrm{O}_{8} \mathrm{Si}_{3}$ & $3 g / 1$ & 13.33 & 17.33 & 52.00 & 52.00 & 10.67 & 9.33 & 44.00 & 28.00 \\
\hline $\mathrm{K}_{2} \mathrm{SiO}_{2}$ & $2 \mathrm{ml} / 1$ & 12.00 & 20.00 & 56.00 & 61.33 & 9.33 & 6.67 & 48.00 & 32.00 \\
\hline $\mathrm{K}_{2} \mathrm{SiO}_{2}$ & $3 \mathrm{ml} / 1$ & 8.00 & 14.67 & 52.00 & 48.00 & 5.33 & 5.33 & 41.33 & 26.67 \\
\hline Del-Cup & $5 \mathrm{ml} / 1$ & 18.67 & 22.67 & 68.00 & 60.00 & 14.67 & 13.33 & 48.00 & 36.00 \\
\hline Control & - & 58.67 & 72.00 & 356.00 & 356.00 & 52.00 & 48.00 & 212.00 & 204.00 \\
\hline L.S.D. 0.05 & & 6.517 & 4.699 & 7.320 & 8.731 & 4.788 & 5.383 & 8.340 & 7.902 \\
\hline
\end{tabular}

Table 7. Effect of silica sources on discolored grain percent of rice brown spot disease on Egyptian hybrid rice one cultivar under field conditions in 2015 and 2016 seasons.

\begin{tabular}{lccc}
\hline & & \multicolumn{2}{c}{$\begin{array}{c}\text { Discolored } \\
\text { grain \% }\end{array}$} \\
& Conc. & $\mathbf{2 0 1 5}$ & $\mathbf{2 0 1 6}$ \\
\hline White rice husk & $0.45 \mathrm{~g} / 1$ & 13.33 & 18.67 \\
Rice husk nanoparticles White & $0.45 \mathrm{~g} / 1$ & 9.33 & 13.33 \\
rice Straw & $0.45 \mathrm{~g} / 1$ & 21.33 & 25.33 \\
$\mathrm{Rice} \mathrm{Straw}$ nanoparticles $_{\mathrm{Mg}_{2} \mathrm{O}_{8} \mathrm{Si}_{3}}$ & $0.45 \mathrm{~g} / 1$ & 14.67 & 21.33 \\
$\mathrm{Mg}_{2} \mathrm{O}_{8} \mathrm{Si}_{3}$ & $2 \mathrm{~g} / 1$ & 14.67 & 18.67 \\
$\mathrm{~K}_{2} \mathrm{SiO}_{2}$ & $3 \mathrm{~g} / 1$ & 10.67 & 14.67 \\
$\mathrm{~K}_{2} \mathrm{SiO}_{2}$ & $2 \mathrm{ml} / 1$ & 9.33 & 16.00 \\
Del-Cup & $3 \mathrm{ml} / 1$ & 5.33 & 10.67 \\
$\mathrm{Control}$ & $5 \mathrm{ml} / 1$ & 12.00 & 21.33 \\
L.S.D. 0.05 & - & 52.00 & 58.67 \\
\hline
\end{tabular}

Agronomic and yield studied characters are affected significantly by different treatments on Egyptian Hybrid one rice cultivar.

The effect of different silica treatments on agronomic and yield characters were showed in tables 9, 10 and 11 . The results indicated that different treatments significantly affected panicle length, number of filled grains per panicle, number of unfilled spikelets per panicle, 1000-grain weight, and grain yield and harvest index. Plant height and number of tillers per hill did not affect by the treatments. Application of RHNPs, $\mathrm{K}_{2} \mathrm{SiO}_{2}$ 2 and $3 \mathrm{~g} / 1$ or Del-Cup produced the highest values of panicle length, number of filled grains per panicle, 1000-grain weight and grain yield. Control treatment (tap water spray) recorded the lowest values of panicle length, number of filled grains per panicle, 1000-grain weight, grain yield and harvest index. Control and white rice straw application produced the highest values of number of unfilled spikelets per panicle. All the treatments increased the harvest index significantly over the control without any significant differences among them. Moghadam and Heidarzadeh 2014 found that by applying silica to rice plants, plant height, number of tillers, leaf area, leaf stem and total dry weight and silicon density in leaf texture and stem and a progressive process which in tillering stage was significant $1 \%$ level. Also by applying silica at different levels there was a witness of increasing in grain yield that was significant at $5 \%$ level. They suggested that rice husk and its ash can be used as recyclable mineral nutrient instead of chemical fertilizer.

Table 9. Effect of silica sources on plant height, no. of tillers and panicle length on Egyptian hybrid rice one cultivar under field conditions in 2015 and 2016 seasons.

\begin{tabular}{|c|c|c|c|c|c|c|c|}
\hline \multirow{2}{*}{ Treatments } & \multirow{2}{*}{ Conc. } & \multicolumn{2}{|c|}{ Plant height cm } & \multicolumn{2}{|c|}{ No. of tillers hill ${ }^{-1}$} & \multicolumn{2}{|c|}{ Panicle length $\mathrm{cm}$} \\
\hline & & 2015 & 2016 & 2015 & 2016 & 2015 & 2016 \\
\hline White rice husk & $0.45 \mathrm{~g} / 1$ & 98.33 & 98.00 & 26.00 & 26.07 & 24.04 & 24.03 \\
\hline Rice husk nanoparticles White & $0.45 \mathrm{~g} / 1$ & 100.00 & 98.00 & 25.67 & 25.60 & 25.07 & 25.00 \\
\hline rice Straw & $0.45 \mathrm{~g} / 1$ & 99.00 & 98.33 & 25.33 & 25.13 & 24.17 & 23.97 \\
\hline Rice Straw nanoparticles & $0.45 \mathrm{~g} / 1$ & 100.67 & 99.33 & 25.33 & 26.33 & 23.93 & 23.73 \\
\hline $\mathrm{Mg}_{2} \mathrm{O}_{8} \mathrm{Si}_{3}$ & $2 \mathrm{~g} / 1$ & 100.00 & 98.67 & 26.17 & 26.00 & 24.18 & 24.03 \\
\hline $\mathrm{Mg}_{2} \mathrm{O}_{8} \mathrm{Si}_{3}$ & $3 g / 1$ & 99.00 & 97.00 & 26.27 & 26.17 & 24.30 & 24.20 \\
\hline $\mathrm{K}_{2} \mathrm{SiO}_{2}$ & $2 \mathrm{ml} / 1$ & 99.33 & 97.00 & 26.67 & 25.83 & 25.10 & 25.02 \\
\hline $\mathrm{K}_{2} \mathrm{SiO}_{2}$ & $3 \mathrm{ml} / 1$ & 99.33 & 97.33 & 26.33 & 26.00 & 25.00 & 25.01 \\
\hline Del-Cup & $5 \mathrm{ml} / 1$ & 98.33 & 97.67 & 26.33 & 26.07 & 25.10 & 25.03 \\
\hline Control & - & 100.33 & 97.00 & 26.07 & 25.13 & 23.93 & 23.67 \\
\hline L.S.D. 0.05 & & NS & NS & NS & NS & 0.34 & 0.66 \\
\hline
\end{tabular}


Table 10. Effect of silica sources on no. of filled grain, no. of unfilled spikelets and 1000-grain weight on Egyptian hybrid rice one cultivar under field conditions in 2015 and 2016 seasons.

\begin{tabular}{|c|c|c|c|c|c|c|c|}
\hline \multirow[t]{2}{*}{ Treatments } & & \multicolumn{2}{|c|}{$\begin{array}{l}\text { No. of filled grain } \\
\text { panicle }^{-1}\end{array}$} & \multicolumn{2}{|c|}{$\begin{array}{c}\text { No. of unfilled } \\
\text { spikelets panicle }\end{array}$} & \multicolumn{2}{|c|}{ 1000-grain weight } \\
\hline & & 2015 & 2016 & 2015 & 2016 & 2015 & 2016 \\
\hline White rice husk & $0.45 \mathrm{~g} / 1$ & 90.80 & 90.07 & 9.33 & 9.93 & 24.43 & 24.07 \\
\hline Rice husk nanoparticles White & $0.45 \mathrm{~g} / 1$ & 93.97 & 93.67 & 6.03 & 6.13 & 25.13 & 24.37 \\
\hline rice Straw & $0.45 \mathrm{~g} / 1$ & 89.67 & 89.07 & 10.33 & 10.93 & 24.20 & 24.17 \\
\hline Rice Straw nanoparticles & $0.45 \mathrm{~g} / 1$ & 93.10 & 91.50 & 6.90 & 8.50 & 24.17 & 24.13 \\
\hline $\mathrm{Mg}_{2} \mathrm{O}_{8} \mathrm{Si}_{3}$ & $2 \mathrm{~g} / 1$ & 93.07 & 93.02 & 5.93 & 6.60 & 24.63 & 24.03 \\
\hline $\mathrm{Mg}_{2} \mathrm{O}_{8} \mathrm{Si}_{3}$ & $3 \mathrm{~g} / 1$ & 93.47 & 92.37 & 5.53 & 5.17 & 24.47 & 24.03 \\
\hline $\mathrm{K}_{2} \mathrm{SiO}_{2}$ & $2 \mathrm{ml} / 1$ & 94.03 & 94.57 & 5.97 & 5.43 & 25.17 & 24.50 \\
\hline $\mathrm{K}_{2} \mathrm{SiO}_{2}$ & $3 \mathrm{ml} / 1$ & 94.40 & 94.83 & 5.60 & 5.57 & 25.20 & 24.73 \\
\hline Del-Cup & $5 \mathrm{ml} / 1$ & 95.05 & 94.90 & 5.97 & 5.39 & 25.23 & 24.77 \\
\hline Control & - & 88.50 & 88.07 & 11.50 & 11.93 & 23.60 & 23.13 \\
\hline L.S.D. 0.05 & & 1.29 & 1.40 & 1.26 & 1.43 & 0.56 & 0.66 \\
\hline
\end{tabular}

Table 11. Effect of silica sources on grain yield, straw yield and harvest index on Egyptian hybrid rice one cultivar under field conditions in 2015 and 2016 seasons.

\begin{tabular}{|c|c|c|c|c|c|c|c|}
\hline \multirow{2}{*}{ Treatments } & \multirow{2}{*}{ Conc. } & \multicolumn{2}{|c|}{${\text { Grain yield } \mathrm{t} \mathrm{ha}^{-1}}^{-1}$} & \multicolumn{2}{|c|}{ Straw yield $\mathrm{t} \mathrm{ha}^{-1}$} & \multicolumn{2}{|c|}{ Harvest index } \\
\hline & & 2015 & 2016 & 2015 & 2016 & 2015 & 2016 \\
\hline White rice husk & $0.45 \mathrm{~g} / 1$ & 12.14 & 12.09 & 14.60 & 13.97 & 0.454 & 0.464 \\
\hline Rice husk nanoparticles White & $0.45 \mathrm{~g} / 1$ & 12.90 & 12.83 & 14.48 & 14.42 & 0.471 & 0.471 \\
\hline rice Straw & $0.45 \mathrm{~g} / 1$ & 12.09 & 12.04 & 14.11 & 13.85 & 0.461 & 0.465 \\
\hline Rice Straw nanoparticles & $0.45 \mathrm{~g} / 1$ & 12.04 & 12.16 & 14.24 & 14.12 & 0.458 & 0.463 \\
\hline $\mathrm{Mg}_{2} \mathrm{O}_{8} \mathrm{Si}_{3}$ & $2 \mathrm{~g} / 1$ & 12.44 & 12.35 & 14.43 & 14.23 & 0.463 & 0.465 \\
\hline $\mathrm{Mg}_{2} \mathrm{O}_{8} \mathrm{Si}_{3}$ & $3 g / 1$ & 12.51 & 12.37 & 14.24 & 14.03 & 0.468 & 0.469 \\
\hline $\mathrm{K}_{2} \mathrm{SiO}_{2}$ & $2 \mathrm{ml} / 1$ & 12.85 & 12.78 & 14.52 & 14.28 & 0.469 & 0.472 \\
\hline $\mathrm{K}_{2} \mathrm{SiO}_{2}$ & $3 \mathrm{ml} / 1$ & 12.90 & 12.88 & 14.56 & 14.38 & 0.470 & 0.472 \\
\hline Del-Cup & $5 \mathrm{ml} / 1$ & 13.02 & 12.98 & 14.62 & 14.42 & 0.471 & 0.474 \\
\hline Control & - & 11.75 & 11.68 & 14.29 & 13.98 & 0.451 & 0.455 \\
\hline L.S.D. 0.05 & & 0.25 & 0.18 & NS & $0 . \mathrm{NS}$ & 0.018 & 0.011 \\
\hline
\end{tabular}

\section{CONCLUSION}

It can be concluded that, $\mathrm{Si}$ plays as cuticle role in the resistance of some plants to disease and more information has to be delivered to farmers and rice grown to assist the agricultural field to effectively manage and control plant diseases.

\section{REFERENCES}

Abed-Ashtiani, F., Kadir, J.-B., Selamat, A.-B., Hanif, A. H. B.-M., and Nasehi, A. 2012. Effect of foliar and root application of silicon against rice blas fungus in MR219 rice variety. Plant Pathol. J. 28, 164-171.

Ahmad A., M. Afzal, A.U.H. Ahmad, and M. Tahir. 2013. effect of foliar application of silicon on yield and quality of rice (Oryza sativa 1). Vol. XLVI, No. 3 (155) 21- 28.

Brunings, A. M., Datnoff, L. E., Ma, J. F., Mitani, N., Nagamura, Y., Rathinasabapathi, B., and Kirst, M. 2009. Differential gene expression of rice in response to silicon and rice blast fungus Magnaporthe oryzae. Annals of Applied Biology 155, 1-10.

Dominic, M. C.D; P.M Sabura Begum; R. Joseph; D. Joseph; P. Kumar and E.P. Ayswarya (2013). Synthesis, characterization and application of rice husk nano-silica in natural rubber. International J. Science, Environment and Technology, 2 (5): 1027-1035.
Foy, C. D. 1992. Soil chemical factors limiting plant root growth. Adv. Soil Sci. 19, 97-149.

Gao, D, Cai, K., Chen, J., Luo, S., Zeng, R., Yang, J., and Zhu, X. 2011.Silicon enhances photochemical efficiency and adjusts mineral nutrient absorption in Magnaporthe oryzae infected rice plants.Acta Physiol Plant33,675-682.

Ghareeb, H., Bozso, Z., Ott, P. G., Repenning, C., Stahl, F., and Wydra, K. 2011. Transcriptome of silicon-induced resistance against Ralstonia solanacearum in the silicon non-accumulator tomato implicates priming effect. Physiological and Molecular Plant Pathology 75, 83-89.

Gholami, Y. and A. Falah. 2013. Effects of two different sources of silicon on dry matter production, yield and yield components of rice, Tarom Hashemi variety and 843 Lines. Intl J Agri Crop Sci. Vol., 5 (3), 227-231.

Gomez, K. N. and A. A. Gomez (1984). Statistical procedures for agricultural research. Wiley and Sons, Inc., New York $2^{\text {nd }}$ ed., pp.68.

Jones, L. H. P., Handreck, K. A. 1967. Silica in soils, plants and animals. Advances in Agronomy 19, 107-149.

Kalboush, Zeinab, A., W.E.Gaber, and A.A. Hassan. (2017). Biogenic Silica Nanoparticles, Synthesis, Characterization and antifungal activity against two rice pathogenic fungi. Egypt. J. Agric. Res, 95 (2) 543-557. 
Kim, S. G., Kim, K. W., Park, E. W., and Choi, D. 2002. Silicon-induced cell wall fortification of rice leaves: a possible cellular mechanism of enhanced host resistance to blast. The American Phytopathological Society 92, 10951103.

Liang, Y. C., Zhang, W. H., Chen, Q., and Ding, R. X. 2005. Effects of silicon on H+-ATPase and $\mathrm{H}+-\mathrm{PPase}$ activity, fatty acid composition and fluidity of tonoplast vesicles from roots of saltstressed barley (Hordeum vulgare L.). Environmental and Experimental Botany 53, 29-37.

Ma, J.F. and E. Takahashi (2002). Soil fertilizer and plant silicon research in Japan. Amsterdam, the Netherlands. Elsevier.

Moghadam, M.R.K. and H. Heidarzadeh. 2014. Response of silicate fertilizer effects, rice husk and rice husk ash on rice paddy growth and seed yield (Shiroodi cultivar) in pot condition. Intl. J. Farm. \& Alli. Sci. Vol., 3 (4): 449-452.

Ning, D.: A. Song;, F. Fan; Z. Li1 and Y. Liang (2014). Effects of Slag-Based Silicon Fertilizer on Rice Growth and Brown-Spot Resistance. PLOS ONE 9, Issue 7 e102681 www.plosone.org

Nwugo, C. C., and Huerta, A. J. 2011. The Effect of Silicon on the Leaf Proteome of Rice (Oryza sativa L.) Plants under Cadmium-Stress. Journal of Proteome Research 10, 518-528.

Ou, S.H. 1985. Rice Diseases. 2nd ed. Commonwealth Mycological Institute, England 380.

Park, J.-J., Kim, K. W., Park, T.-J., Park, E. W., and Kim, Y. 2006. Solid-state NMR spectroscopy of silicon-treated rice with enhanced host resistance against blast. Analytic sciences 22, 645-648.

Rodrigues, F. A., Benhamou, N., Datnoff, L. E., Jones, J. B., and Belanger, R. 2003. Ultrastructural and cytochemical aspects of silicon-mediated rice blast resistance. Phytopathology 93, 535546.

Rodrigues, F. A., Jurick II, W. M., Datnoff, L. E., Jones, J. B., and Rollins, J. A. 2005. Silicon influences cytological and molecular events in compatible and incompatible rice-Magnaporthe grisea interactions. Physiological and Molecular Plant Pathology 66, 144-159.

Rodrigues, F. A., McNally D. J., Datnoff, L. E., Jones, J. B., Labbé, C., Benhamou, N., Menzies, J. G., and Bélanger, R. R. 2004. Silicon enhances the accumulation of diterpenoid phytoalexins in rice: a potential mechanism for blast resistance. Phytopathology 94, 177-183.

Seebold, K. W., Kucharek, T. A., Datnoff, L. E., Correa-Victoria, F. J., and Marchetti, M. A. 2001. The influence of silicon on components of resistance to blast in susceptible, partially resistant, and resistant cultivars of rice. Phytopathology 91, 63-69.

Shetty, R., Jensen, B., Shetty, N. P., Hansen, M., Hansen, C. W., Starkey, K. R., and Jorgensen, H. J. L. 2012. Silicon induced resistance against powdery mildew of roses caused by Podosphaera pannosa. Plant Pathology 61, 120-131.

Sun, W., Zhang, J., Fan, Q., Xue, G., Li, Z., and Liang, Y. 2010. Silicon-enhanced resistance to rice blast is attributed to silicon-mediated defence resistance and its role as physical barrier. Eur J Plant Pathol. 128, 39-49.

Townsend, G.R. and J.W. Huberger (1943). Methods of estimating losses caused by diseases in fungicide experiments. Plant Dis.Reptr.27 (7): 340-343.

Van Bockhaven, J., De Vleesschauwer, D., and Höfte, M. 2012. Towards establishing broad-spectrum disease resistance in plants: silicon leads the way. Journal of experimental botany. Doi: $10.1093 / \mathrm{jxb} / \mathrm{ers} 329$.

Webster, R. K., and Gunnell, P. S. 1992. "Compendium of rice diseases," the American Phytopathological Society, St. Paul, Minnesota, USA.

Zeyen, R. J., Ahlstrand, G. G., and Carver, T. L. W. 1993. X-Ray-Microanalysis of Frozen-Hydrated, FreezeDried, and Critical-Point Dried Leaf Specimens Determination of Soluble and Insoluble ChemicalElements at Erysiphe-Graminis Epidermal-Cell Papilla Sites in Barley Isolines Containing Ml-O and Ml-O Alleles. Canadian Journal of BotanyRevue Canadienne De Botanique 71, 284-296.
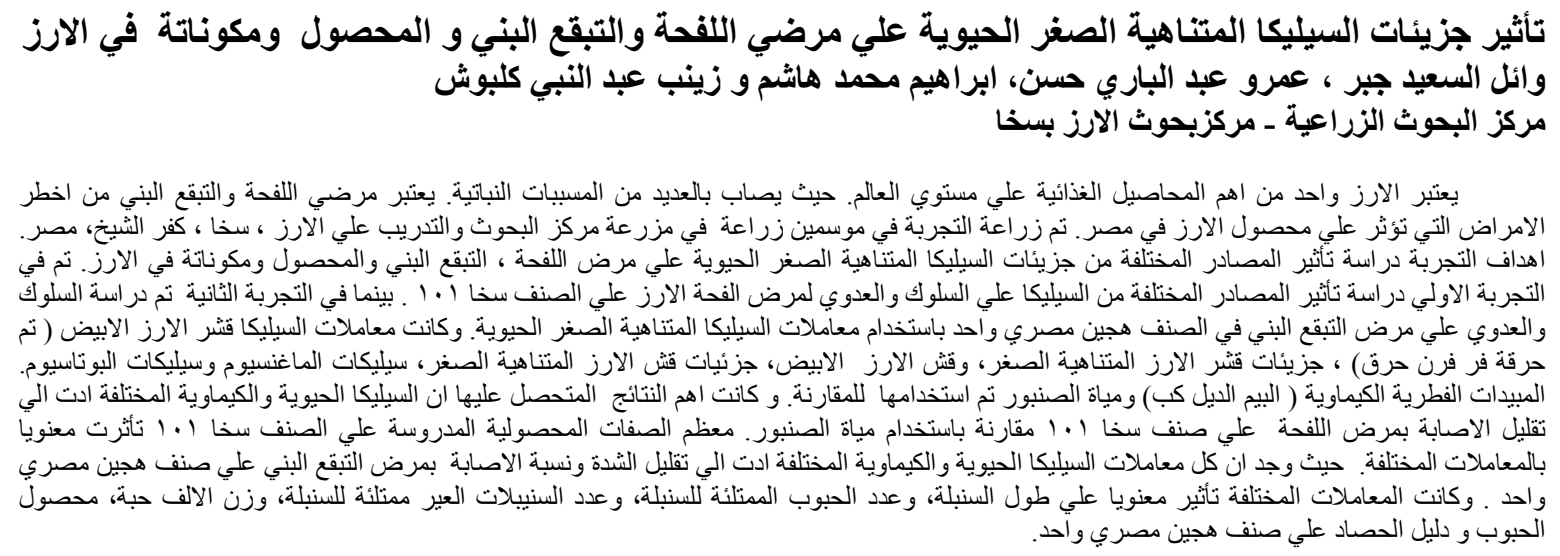